INTERNATIONAL JOURNAL OF MULTIDisciplinARY RESEARCH AND ANALYSis

ISSN(print): 2643-9840, ISSN(online): 2643-9875

Volume 04 Issue 11 November 2021

DOI: 10.47191/ijmra/v4-i11-42, Impact Factor: 6.072

Page No.- $1743-1747$

\title{
How to Habits of Drinking Alcohol "SOPI" in Community?- Dental Caries Status
}

\author{
Quroti A'yun ${ }^{1}$, Bonevansius Virmas ${ }^{2}$, Aryani Widayati ${ }^{3}$ \\ 1,2,3 Department of Dental Health, Poltekkes Kemenkes Yogyakarta, Yogyakarta, Indonesia
}

ABSTRACT: Dental and oral health problems in the people of East Nusa Tenggara Province are in the high category. The people of Coal Village have a habit of drinking sopi, a traditional alcoholic beverage. Frequently drinking alcoholic beverages for long duration has a negative risk to the oral health. Sopi is one of the traditional alcoholic beverages, fermented from Enau (palm) tree plants. The purpose of this research is relationship between the habits of drinking sopi and the status of dental caries. Method: This is a research of Analytical Survey. This research was conducted in November to December 2019. The population on this research was the society of sopi drinkers. The total sampling was 76 people. The data collecting of the sopi drinking habits was carried out by completing the checklists; the data of the dental caries status was obtained by direct examinations. The data analysis used the test of Kendall's Tau c. Results: The duration of drinking sopi was classified in the old category (93,4\%); the frequency of drinking sopi was classified in the frequent category $(63,2 \%)$; the volume of the drunk sopi was classified in the lots category $(61,8 \%)$; the habits of drinking sopi was classified in the heavy category (93.4\%); and the dental caries status was classified in the high criterion (52,6\%). Based on the correlation test results, that there was no relationship between the time duration, frequency, volume, and the habits of drinking sopi with the status of dental caries $(P<0,05)$. Conclusion: There was no relationship between the habits of drinking sopi and the status of dental caries.

KEYWORDS: Sopi drinking habits, dental caries status

\section{INTRODUCTION}

Oral health is an integral component of general health. It is also becoming clear that the risk factors for oral disease are often the same as those involved in common diseases. Caries is a disease of the hard tissues of the teeth, namely enamel, dentin and cementum caused by the activity of a microorganism in a fermentable carbohydrate. The sign is the demineralization of the hard tooth tissue which is then followed by the destruction of the organic matter [1-3].

Demineralization and destruction of organic matrix caused by caries originates from acid-producing bacteria (Streptococcus muntas, Aktinomyces viscosus, Lactobacillus species, and Streptococcus sanguis) in plaque with food substrates over a long period of time. The bacteria produce lactic acid which causes electrochemical changes and an outflow of calcium ions from mineralized teeth. An early sign of a new carious lesion is the appearance of white chalky patches on the tooth surface, indicating an area of demineralized enamel. This is called an incipient carious lesion "microcavity", as the lesion continues to demineralize, may turn brown and eventually turn into a cavity. Before the cavity forms, this process is reversible, and the tooth structure is lost and cannot be regenerated. A brown spot that is dull in appearance may be a sign of active caries. Caries is classified into three parts, namely enamel, dentin and pulp caries $[4,5]$.

Public awareness of dental and oral health is also one of the triggers for dental caries, one of the triggering factors is drinking alcoholic beverages is a habit that is almost inseparable in people's lives in some areas. Alcohol is America's number one drug problem by any standard of measurement, the number of people who abuse it, the number of injuries and deaths it causes, the total cost, and the social and economic burden on society of the breakdown of families and loss of income. There are two factors that cause alcohol abuse, namely individual and environmental factors [6-8].

Based on the results of the 2018 Basic Health Research, there were 2 provinces with the highest prevalence of consuming alcoholic beverages, namely East Nusa Tenggara and North Sulawesi of 15\%. The proportion of dental and oral health problems in East Nusa Tenggara is still high above 45\% [9]. 


\section{How to Habits of Drinking Alcohol "SOPI" in Community?- Dental Caries Status}

East Nusa Tenggara Province has local alcoholic fermented drinks, namely "Laru" and "Sopi". Sopi is made from fermented water taken from the palm tree. The habit of consuming alcoholic beverages with a long frequency and duration has a negative risk to the health of the oral cavity because it interferes with the acidity of the salivary $\mathrm{pH}$ which functions to maintain the condition of the oral cavity in a balanced state [6].

The results of preliminary observations related to the habit of consuming alcoholic beverages of the type of sopi show that the residents of Coal Village are no different from the habits of the Manggarai people in general sopi is always used in every aspect of the lives of its citizens, both in governmental ceremonies and in traditional ceremonies.

\section{METHOD AND MATERIAL}

The type of research used in this study is an analytical survey with a Cross Sectional approach, a research that studies the relationship between risk factors (independent) and effect factors (dependent), which conducts observations or measurements of variables once and at the same time [10]. The population in this study is the people who consume alcoholic beverages of the type of sopi. Sampling in this study using quota sampling technique with a total sample of 76 respondents. This research was conducted in Coal Village, Kuwus District, West Manggarai Regency in November-December 2019.

The method of collecting data on the habit of consuming sopi was done by direct interviews with respondents according to the questions provided in the check list format about the habit of consuming sopi. Dental caries status is done by directly checking the condition of the respondent's dental health status. Analysis of the data used is the Kendall Tau correlation test which aims to determine the relationship between the habit of consuming alcoholic beverages such as Sopi with dental caries status.

\section{RESULT}

Table 1. Frequency distribution of respondent characteristics

\begin{tabular}{|c|c|c|c|}
\hline No. & Variable & N & $\begin{array}{c}\text { Percentage } \\
(\%)\end{array}$ \\
\hline 1 & Age & & \\
\hline & $17-15$ years & 11 & 1.5 \\
\hline & $26-45$ years & 35 & 46.1 \\
\hline & $46-65$ years & 28 & 36.8 \\
\hline & $>66$ years & 2 & 2.6 \\
\hline & total & 76 & 100 \\
\hline 2 & Type of work & & \\
\hline & Farmer & 61 & 80.3 \\
\hline & Entrepreneur & 5 & 6.6 \\
\hline & Village apparatus & 2 & 2.6 \\
\hline & Motorcycle taxis driver & 3 & 3.9 \\
\hline & Student & 5 & 6.6 \\
\hline & total & 76 & 100 \\
\hline
\end{tabular}

Table 1 shows that the age range of 26-45 years has the highest number of respondents 35 respondents with a percentage of $46.1 \%$ while the type of work with the highest number of respondents was as a farmer as many as 61 people with a percentage of 80.3 percent.

Table 2. Frequency distribution of habits of drinking sopi

\begin{tabular}{|l|l|l|l|}
\hline No. & Habits of drinking sopi & N & Percentage (\%) \\
\hline 1 & Light & 5 & 6.6 \\
\hline 2 & Heavy & 71 & 93.4 \\
\hline \multicolumn{2}{|l|}{ Total } & 76 & 100 \\
\hline
\end{tabular}

Table 2 shows that the respondents have a habit of consuming sopi in the heavy category as many as 71 respondents with a percentage of $93.4 \%$. 
How to Habits of Drinking Alcohol "SOPI" in Community?- Dental Caries Status

Table 3. Frequency distribution of dental caries status

\begin{tabular}{|l|l|l|l|}
\hline No. & Dental caries status & N & $\begin{array}{l}\text { Percentage } \\
(\%)\end{array}$ \\
\hline 1 & Low caries & 12 & 15.8 \\
\hline 2 & Medium caries & 24 & 31.6 \\
\hline 3 & High caries & 40 & 52.6 \\
\hline Total & & 76 & 100 \\
\hline
\end{tabular}

Table 3 shows that the dental caries status with high criteria has the most respondents 40 respondents with a percentage of $52.6 \%$.

Table 4. Description of the length of time consuming sopi with dental caries status

\begin{tabular}{|c|c|c|c|c|c|c|c|c|}
\hline \multirow{2}{*}{ Period } & \multicolumn{5}{|c|}{ Dental caries status } & \multicolumn{2}{c|}{ Total } \\
\cline { 2 - 9 } & \multicolumn{2}{|c|}{ Low } & \multicolumn{2}{|c|}{ Medium } & \multicolumn{2}{c|}{ High } & \multicolumn{2}{c|}{} \\
\cline { 2 - 9 } & $\mathrm{N}$ & $\%$ & $\mathrm{~N}$ & $\%$ & $\mathrm{~N}$ & $\%$ & $\mathrm{~N}$ & $\%$ \\
\hline Recently & 3 & 60 & 2 & 100 & 0 & 0 & 5 & 100 \\
\hline Long time & 9 & 12.7 & 2 & 24 & 40 & 56.3 & 71 & 100 \\
\hline Total & 12 & 15.8 & 24 & 31.6 & 40 & 53.6 & 76 & 100 \\
\hline
\end{tabular}

The results of the cross-tabulation study between the length of time consuming sopi (years) and caries status showed that respondents in the category of consuming sopi had long had dental caries status with high criteria of 40 respondents with a percentage of $56.3 \%$.

Table 5. Description of Frequency of drinking Sopi with dental caries status

\begin{tabular}{|c|c|c|c|c|c|c|c|c|}
\hline \multirow{3}{*}{ Frequency of Drinking Sopi } & \multicolumn{6}{|c|}{ Dental caries status } & \multirow{2}{*}{\multicolumn{2}{|c|}{ Total }} \\
\hline & \multicolumn{2}{|c|}{ Low } & \multicolumn{2}{|c|}{ Medium } & \multicolumn{2}{|c|}{ High } & & \\
\hline & $\mathrm{N}$ & $\%$ & $\mathrm{~N}$ & $\%$ & $\mathrm{~N}$ & $\%$ & $\mathrm{~N}$ & $\%$ \\
\hline Not often & 8 & 28.6 & 7 & 25.0 & 13 & 46.4 & 28 & 100 \\
\hline Often & 4 & 8.3 & 17 & 35.4 & 27 & 56.3 & 48 & 100 \\
\hline Total & 12 & 15.8 & 24 & 60.4 & 40 & 52.6 & 76 & 100 \\
\hline
\end{tabular}

The results of the cross tabulation study between the frequency of consuming sopi (months) and dental caries status, it is known that respondents with the frequency of consuming sopi in the frequent category have dental caries status with high criteria as many as 27 respondents $56.3 \%$

Table 6. Description of volume of sopi consumed with dental caries status

\begin{tabular}{|c|c|c|c|c|c|c|c|c|}
\hline \multirow{3}{*}{ Volume Sopi } & \multicolumn{6}{|c|}{ Dental caries status } & \multirow{2}{*}{\multicolumn{2}{|c|}{ Total }} \\
\hline & \multicolumn{2}{|c|}{ Low } & \multicolumn{2}{|c|}{ hedium } & \multicolumn{2}{|l|}{ igh } & & \\
\hline & $\mathrm{N}$ & $\%$ & $N$ & $\%$ & $N$ & $\%$ & $N$ & $\%$ \\
\hline Many & 8 & 27.6 & 7 & 24.1 & 14 & 48.3 & 29 & 100 \\
\hline Not many & 4 & 8.5 & 17 & 36.2 & 26 & 55.3 & 47 & 100 \\
\hline Total & 12 & 15.8 & 24 & 60.4 & 40 & 52.6 & 76 & 100 \\
\hline
\end{tabular}

The results of the cross tabulation study between the volume of sopi consumed (liters) and dental caries status showed that respondents with the habit of consuming large volumes of sopi had a high category of caries status as many as 26 respondents with a percentage of $55.3 \%$. 


\section{How to Habits of Drinking Alcohol "SOPI" in Community?- Dental Caries Status}

Table 7. Description of habits of drinking sopi and dental caries status

\begin{tabular}{|c|c|c|c|c|c|c|c|c|}
\hline \multirow{2}{*}{ Habits of drinking sopi } & \multicolumn{5}{|c|}{ Dental caries status } & \multicolumn{3}{|c|}{ Total } \\
\cline { 2 - 10 } & \multicolumn{2}{|c|}{ Low } & \multicolumn{2}{|c|}{ Medium } & \multicolumn{2}{c|}{ High } & \multicolumn{2}{c|}{} \\
\cline { 2 - 10 } & $\mathrm{N}$ & $\%$ & $\mathrm{~N}$ & $\%$ & $\mathrm{~N}$ & $\%$ & $\mathrm{~N}$ & $\%$ \\
\hline Light & 3 & 60 & 2 & 40 & 0 & 0 & 5 & 100 \\
\hline Heavy & 9 & 12.7 & 22 & 31 & 40 & 56.3 & 71 & 100 \\
\hline Total & 12 & 15.8 & 24 & 31.6 & 40 & 52.6 & 76 & 100 \\
\hline
\end{tabular}

The results of the cross tabulation study between the habit of consuming sopi and dental caries status, it is known that respondents with the habit of consuming sopi in the heavy category have dental caries status with high criteria as many as 40 respondents with a percentage of $56.3 \%$.

Table 7. Correlation analysis of habits of drinking sopi and dental caries status

\begin{tabular}{|c|l|l|c|}
\hline Variable & $\mathrm{p}$-value & $\alpha$ & orrelation coefficient \\
\hline The length of time for drinking sopi & 0.020 & 0.05 & 0.172 \\
\hline Frequency of drinking sopi & 0.166 & 0.05 & 0.166 \\
\hline Volume of drinking sopi & 0.242 & 0.05 & 0.141 \\
\hline Habits of drinking sopi & 0.020 & 0.05 & 0.172 \\
\hline
\end{tabular}

The results of the correlation test using Kendall's Tau analysis between the length of time consuming, frequency, volume and habit of consuming sopi with dental caries status, the $p$-value of the four variables measured is greater than 0.05 , so it can be concluded that there is no relationship between length of time, frequency, volume and habit of consuming sopi with dental caries status.

\section{DISCUSION}

The results of research on the community of Coal Village, Kuwus District, West Manggarai Regency showed that respondents who worked as farmers were 61 people (80.3\%), entrepreneurs 5 people (6.6\%), village officials 2 people (2.6), motorcycle taxi drivers 3 people $(3.9 \%)$, students 5 people $6.6 \%$. This is in accordance with the statement from the Coal Village Head to researchers that most of the community members work in the agricultural sector.

The results showed that 11 respondents (14.5\%) aged 12-25 years, 35 people (46.1\%), 46-65 years old 28 (36.8\%), and age 66 years and over 2 people (2.6\%). This is in accordance with the results of interviews with respondents that at first they consumed sopi when they began to be involved in traditional ceremonies and parties since their teens.

The results showed that the highest number of respondents in the habit of consuming sopi was in the heavy category as many as 71 people (93.4\%) and as many as 5 people (6.6\%) included in the light category in the habit of consuming sopi. The results of interviews between researchers and respondents stated that the activity of consuming sopi during traditional ceremonies and other events such as wedding parties, new welcoming parties, school parties, when gathering with friends who like sopi, when the air temperature feels cold. Cold air conditions in some areas and the condition of people who work as fishermen make alcoholic beverages an option to warm the body. This habit later developed into a culture in society, where this drink is widely consumed also at traditional events or at various celebrations and parties [6].

The results showed that the status of dental caries with low criteria was 12 people $(15.8 \%)$, dental caries with moderate criteria was 24 people (31.6\%), dental caries with high criteria was 40 people (52.6\%). Judging from the results, it is possible that dental caries that occurred in the Coal Village community was caused by the habit or culture of drinking sopi in the local community. Consuming alcoholic beverages can reduce the degree of acidity and volume of saliva. The results showed that there was a decrease in saliva the average $\mathrm{pH}$ value and saliva volume in alcoholic drinkers [11].

The results showed that respondents in the category of consuming sopi have long had dental caries status with a high criterion of 40 respondents with a percentage of $56.3 \%$. The results of the study showed that the high caries status in the Coal Village community was influenced by the long-standing habit of consuming traditional alcoholic beverages such as sopi. The habit of drinking alcoholic beverages with a long frequency and duration has a negative risk for oral health. 


\section{How to Habits of Drinking Alcohol "SOPI" in Community?- Dental Caries Status}

The results showed that the frequency of consuming sopi in the category of frequently having dental caries status with high criteria was 27 respondents $56.3 \%$. The results of the study suggest that the high status of dental caries in the Coal Village community is influenced by the habit of frequently consuming traditional alcoholic beverages such as sopi. The habit of drinking alcoholic beverages with a long frequency and duration has a negative risk for oral health [6].

The results showed that respondents with the habit of consuming sopi with large volumes had a high criteria caries status as many as 26 respondents with a percentage of $34.2 \%$. The results of the study suggest that the high caries status of the Coal Village community is influenced by the habit of consuming large volumes of sopi. Tuak drink has an effect on demineralization of tooth enamel because a low $\mathrm{pH}$ will increase the concentration of hydrogen ions and these ions will damage the hydroxyapatite of tooth enamel [12].

The results showed that respondents with the habit of consuming sopi in the heavy category had a high criteria dental caries status as many as 40 respondents with a percentage of $56.3 \%$. The results of the study suggest that the high caries status of the Coal Village community is influenced by the habit of consuming traditional alcoholic beverages of the type of sopi with volume, frequency and long duration. The habit of drinking alcoholic beverages with a long frequency and duration has a negative risk for oral health [6].

The results of the correlation test using Kendall's Tau showed that the correlation coefficient was 0.172 and the value of $P=$ $0.020(P<0.05)$ thus there was no relationship between the habit of consuming sopi and dental caries status. It can be concluded that the results of this study are contrary to the research of Kaurow et al. that the habit of consuming alcoholic beverages with a long frequency and duration has a negative risk to oral health because it interferes with the acidity of the salivary $\mathrm{pH}$ which functions to keep the oral cavity in good condition state of balance. 8

\section{CONCLUSIONS}

Based on the results of the study, it can be concluded that there is no relationship between the habit of consuming sopi and dental caries status.

\section{ACKNOWLEDGMENT}

This study was done by self- funding from the authors. The authors thank to all partisipants and research assistan.

\section{REFERENCES}

1) Purnama T, Ngatemi IF, Widiyastuti R. Model Mentoring Teachers and Parents as an Efforts for Brushing Teeth Behavior in Preschool Children. Indian J Forensic Med Toxicol 2020;14:3511.

2) Ngatemi N, Kristianto J, Widiyastuti R, Purnama T, Insani RL. Riwayat pemberian susu formula dengan indek def-t pada anak usia dini di TK Pertiwi IV Pondok Labu. JDHT J Dental Hygiene Therapy 2020;1:6-11.

3) [Kidd EAM, Bechal SJ. Dasar-dasar Karies penyakit dan Penanggulangan. EGC, Jakarta, Hal 2013:98-118.

4) Kidd EAM, Fejerskov O. Essentials of dental caries. Oxford University Press; 2016.

5) Yadav K, Prakash S. Dental caries: A microbiological approach. J Clin Infect Dis Pr 2017;2:1-15.

6) Kaurow C. Gambaran status karies peminum alkohol di desa paku weru dua. PHARMACON 2015;4.

7) Burlian P. Patologi Sosial (full text) 2016.

8) Rori P. Pengaruh penggunaan minuman keras pada kehidupan remaja di desa Kali kecamatan Pineleng kabupaten Minahasa. HOLISTIK, J Soc Cult 2016.

9) Kemenkes RI. Hasil Utama Riset Kesehatan Dasar Tahun 2018. Kementrian Kesehatan Republik Indonesia. 2018;1-100.

10) Notoatmodjo S. Metodologi penelitian kesehatan 2010.

11) Rahayu FS, Handajani J. Mengonsumsi minuman beralkohol dapat Menurunkan derajat keasaman dan volume saliva. Dentika Dent J 2010;15:15-9.

12) Noviyanti R. Pengaruh Konsumsi Minuman Tuak Terhadap Erosi Gigi Di Kecamatan Maiwa Kabupaten Enrekang. Makassar Univ Hasanuddin 2014:1-49. 